\title{
Reading Strategy's Failure to Deliver toward Reading Comprehension
}

\author{
A. Gusti Efendy ${ }^{1}$, Gunadi Harry Sulistyo ${ }^{1}$ \\ ${ }^{1}$ Department of English Language Teaching-State University of Malang
}

\section{INFO ARTIKEL}

\section{Riwayat Artikel:}

Diterima: 12-03-2019

Disetujui: 15-08-2019

\section{Kata kunci: \\ reading comprehension; reading strategy; senior high school; pemahaman membaca; strategi membaca; SMA}

\author{
Alamat Korespondensi: \\ A. Gusti Efendy \\ Department of English Language Teaching \\ State University of Malang \\ Jalan Semarang 5 Malang \\ E-mail: rooney.ghost@ gmail.com \\ E-mail: rooney.ghost@gmail.com
}

As a means of communication, language covers four skills: listening, speaking, reading, and writing. Thus, reading is basically a communication which occurs between the writer and the readers through written discourse. The readers who are considered successful in reading are those who are able to negotiate meaning or reconstruct the message covertly written within the text (Sulistyo, 2011). On the other side, (Gebhard, 1996; Sulistyo, 2011) believes that finding the meaning in print and script, under a context of social, by involving both or one of bottom-up and top-down processing methods, and utilizing reading strategies and skills are included in the definition of reading. Besides an important aspect and a significant component of education, reading is also one of the nation's paradigms in people empowering of Indonesia (Zoghi, Mustapha, \& Maasum, 2010). Moreover, (Grabe, 1991; Zare \& Mobarakeh, 2011) claims that reading is an indispensable skill to master and apparently the most crucial skill for L2 learners in an academic context.

Aside from reading skills, reading comprehension is crucial in reading skills. Being proficient in reading is an important utility to obtain information about technology and scientific development, in various sectors of science (Jafari \& Shokrpour, 2012; Permatasari, 2015). However, the process of comprehending English texts is more complex regarding its importance in the education context. (Alfassi, 2004) indicates that reading is defined as a complex cognitive activity which is crucial in obtaining information in modern society. The complexity is depicted by the factors which are influential to the process of understanding in reading. These factors are dominant aspects which have a more significant influence on understanding process. Summarizing (Sanford, 2015) dissertation, both factors which affect reading comprehension and her main concern to investigate in her research cover working memory, vocabulary, prior knowledge, word recognition, reading strategies, and motivation. In line with her, (Gilakjani \& Sabouri, 2016) compile factors influencing reading comprehension from (Koda, 2007; Nergis, 2013). Those factors are vocabulary knowledge, prior knowledge, metacognitive information, reading strategies, syntactic consciousness, and metacognitive recognition. Referring to the various and differing priorities and perspectives of experts in elaborating affecting factors of reading comprehension, (Sulistyo, 2011) outlines that the factors influencing understanding in reading are including several aspects such as linguistics factors, world background knowledge, textual competence, micro reading skills, and reading strategies. In this article, the focus and only aspect suggested by (Sulistyo, 2011) to elaborate further in the following paragraphs is reading strategy. 
Last but not least, the factor which impacts understanding in reading is reading strategies. Although it is mentioned last, all five factors share equal importance in influencing the reading understanding. Technically, reading strategies can be defined as readers' conscious procedures which are carried out intentionally and purposively (Urquhart \& Weir, 2014; Williams \& Moran, 1989). Reading strategies are also strategies employed by skilled readers to comprehend a text and optimizing information and meaning extraction of the text (Gilliam, Magliano, Millis, Levinstein, \& Boonthum, 2007). In line with that, (Permatasari, 2015) defines reading strategy as the process of comprehension utilized by the readers to make sense the text they are reading. She adds that reading strategy can be discovered by conducting a test namely SORS (Survey of Reading Strategy) which was developed by (Mokhtari \& Sheorey, 2002) and MARSI (Metacognitive Awareness of Reading Strategies Inventory). Both instruments are designed to fit academic reading materials only and less applicable if the intended text to be fit with is non-academic texts or leisure reading materials. What differs SORS and MARSI is that, according to (Mokhtari \& Sheorey, 2002), the SORS construction is inspired by the review made upon the previously made instrument, MARSI. Although both instruments are designed to find out the reading strategy used by students, MARSI is specifically designed for native English speaker students. So, (Mokhtari \& Sheorey, 2002) constructed another instrument which is more widely applicable to non-native English speaker students all over the world.

According to (Mokhtari \& Sheorey, 2002), reading comprehension can be illustrated by how skillful the readers are in utilizing reading strategies to help them comprehend texts. In other words, the more strategic the reader is, the better she/he comprehend information within the text (Pressley \& Afflerbach, 2012). (Gredler, 2002) mention this kind of reader as not only a skilled reader but also a good comprehender. The skilled reader has better ability to collaborate reading strategies in order to comprehend text better than the unskilled readers. Thus, the skilled reader looks like know what she/he is reading, and has set of tentative strategies to deal with potential problems impeding her/him from comprehension she/he is striving for by reading the text (Pressley \& Afflerbach, 2012). In conclusion, works made by (Mokhtari \& Sheorey, 2002), which formulate MARSI and SORS respectively, agree that reading comprehension is also strongly related to the reading strategy involved by the readers. Even, in some cases, an accurate reading strategy possesses a dominant role in determining reading comprehension.

In both MARSI and SORS, the reading strategies to be measured are slightly different from the common reading strategies widely known because through the instruments, their developers put numbers of technical reading strategies into three classifications. This is how reading strategies in Mokhtari's and Sheorey's term slightly differs from as well as relates to the common knowledge of reading strategy. Further explanation of both the difference and the relation of both reading strategies perspectives is provided in the paragraph right after the ones below which are elaborating examples of common reading strategies involved by students and the descriptions of each reading strategy classification used in SORS.

As commonly known, there are a lot of reading strategies which are applicable to achieve the purposes mentioned in the initial part of this section. On one hand (Brown \& Lee, 2015) propose that there are ten separated examples of reading strategies which are applicable in a classroom context. The examples are from reading's purpose identification to capitalizing on discourse markers to proceed relationships. On the other hand, (Mokhtari \& Sheorey, 2002) classify several reading strategies into three major broad classifications of reading strategy. The classification is the initial target of the current researcher to discover by conducting this current research before measuring the contribution of which toward reading comprehension. Hence, the focus of the study to measure is only three broad classifications of reading strategies namely global, problem solving, and support.

According to (Mokhtari \& Sheorey, 2002), the global reading strategy is a broad classification which covers intentional and carefully planned technique. By this technique, the students are enabled to monitor or manage their reading. For instance, the practical explanation of broad reading strategies is around having a purpose in mind, analyzing the text's length and organization, and exploiting the involved typographical aids, tables, and figures. The second classification is problem solving strategy which includes the employed set of strategies by readers when they are directly working with the text. This classification is more like strategies of technical adjustment the readers make as they encounter problems in reading. Taking the speed of reading for in stance, when readers understand the beginning part of the text, they tend to read it quite fast, while they found the next part is slightly (or just) more difficult, the readers tend to adjust the reading speed slower to increase the reading affectivity. The other examples include guessing the meaning of unknown terms and re-reading part of the text which is more difficult to understand so readers can comprehend more. The third strategies classification is the support strategies where readers take a supportive mechanism to increase the comprehension of reading. This strategy includes utilities beyond the text or reading materials. Readers' decision to consult a dictionary for unknown words, take note, and underline or highlight important textual parts are the examples of this broad classification of reading strategies.

The last two paragraphs briefly contrast reading strategies in two aforementioned points of view where the common perspectives treat reading strategies as separated applicable and useful properties to help students making sense the ideas within texts they are reading and while the other puts them in classifications. The classification used in SORS is able to put those separated reading strategies into three groups. Taking example from learning strategies formulated by (Brown \& Lee, 2015) such as: identifying the purpose in reading, using graphemic rule and patterns to aid in bottom-up decoding, skimming the text for main ideas, scanning the text for specific information, using semantic mapping or clustering, distinguishing between literal and 
implied meanings, and capitalizing on discourse markers to proceed relationships can be grouped into global reading strategy since they are included in a series of intentional and planned techniques to enhance reading comprehension. The other three strategies by (Brown \& Lee, 2015) like using efficient silent reading techniques for improving fluency, guessing when you are not certain, and analyzing vocabulary are included into problem solving reading strategy because they are in use only if they find relevant constraints in grasping ideas within the texts they are reading. A common problem in reading is difficult words, which according to (Brown \& Lee, 2015), can be mitigated by two problem solving strategies: guessing the meaning and analyzing the vocabulary. Unfortunately, there is no reading strategy proposed by (Brown \& Lee, 2015) which is included in the group of support reading strategy.

In this current research, the target research subject was students of upper secondary level in Malang. English teaching program for these students covers all language skills such as reading, writing, listening, and speaking in various percentage. According to the Ministry of Education and Culture Republic of Indonesia's release of the syllabus (2016), reading skill has the most percentage among the rest of the language skills since the most time required to teach English is spent on teaching reading. Teaching reading skill in upper secondary level focus on the general competence such as identifying social function, text structure, and linguistic elements of a short text. The focus of the short text is functional text which includes descriptive, recount, narrative, analytical exposition, procedure, news item, and explanation texts. So, by the end of the high school year, students are expected to understand the function in a social context of each functional text type. Besides, they are also expected to recognize the structure of each functional text type which is the pre-requisite ability to reproduce each text type in teaching writing skill. Last, linguistic elements are another expected target of the students to master by the end of their high school years. In this current research, the students reading skill will be measured to determine their reading comprehension level in which the instrument to take into use is developed by considering general competence provided by the syllabus issued by the Education and Culture Ministry in order to fit the given teaching material in classroom since public schools teach the students by considering the manual or syllabus provided by the Ministry. So, the developed reading test to measure student's reading comprehension is designed to be familiar for the students since both the teaching activity in the classroom and the developed reading test is inspired by the same source or the syllabus.

Due to the strategic relationship between reading strategies and reading comprehension, research on such topic has been conducted in many countries and various contexts. The following elaborates number of research conducted measuring the correlation between reading strategy and reading comprehension. Research on investigating reading comprehension which is related to reading strategy was conducted by (Abrami et al., 2008). The research turns out that the employed reading strategy varies based on the level of proficiency. They also discover a positive correlation between reading comprehension and the involved strategies that the better pattern of using the strategy which is utilized by students leads to better understanding of the text. Different from the study conducted by (Abrami et al., 2008), identical studies were administered with upper primary school students separately in Belgium and Greece. (Manoli, 2013) was a scientist responsible for the Greek research, while the research in Belgium was under the control of (Tiruneh, De Cock, \& Elen, 2018). These two scientists conducted identical research with similar subjects, yet slightly distinct approach. Both of them demonstrate a positive correlation between reading strategy and reading comprehension with elementary students as the subject. Besides, 106 Iranian students ( 82 female and 24 male) were involved in another research in examining the correlation between reading strategies and reading comprehension. The result demonstrates a statistically significant positive relationship between overall reading strategy and reading comprehension (Nosratinia \& Shakeri, 2013). The study was conducted to measure several reading strategies and the contribution to students' reading comprehension. All three strategies (global, problem solving, and support) of the study are significantly and positively correlated to the reading comprehension in both simultaneous and individual manner.

\section{METHOD}

(Whitley \& Kite, 2013) agree that correlational research design is taken into use to describe linear relationships between two or more occurring variables. Besides demonstrating the correlation between two or more variables, correlation design is employable to measure the contribution value of every correlating variable. Thus, the research design of simple linear regression was deployed in this current research. This study was designed to find out the utilized Support Reading Strategy by students as predictor variable toward reading comprehension (as the criterion variable) and measure its degree of relationship between the reading strategy and reading comprehension. In this current research, the target population intended to measure was the entire students of the public upper level of secondary schools (from the first to the third grade) in the municipal area of Malang, East Java which is around 8.000-9.000 students. This number was determined by considering the online archive of public high schools enrollment in Malang City in its website (siap-ppdb.com) for the last accessible three admission years (2014/15, 2015/16, and 2016/17). The current researcher believed that all public high schools in Malang City provided relatively equivalent education quality to each other compared to the private ones which were separated in wide range by accreditation level which was far from equal. In addition, in the last national examination, the average score achieved Malang City High Schools students was the highest in East Java Province as reported by mass media (Musya'idah \& Effendy, E. Santoso, 2016; Widyawati, 2017). This indicated 
that the education quality was rising in similar rate among the public senior high schools in the municipal area of Malang. Due to the great number of population, the researcher decided to take samples to represent the whole research population. Regarding the condition of the field, the current researcher's further decision was deploying proportionate stratified random sampling to pick samples. The consideration of picking such a sampling method was based on the fact that there is stratification which differentiates schools into three groups (Margono, 2004). Besides, each school was relatively proportional in distribution in the sense of the number of students admitted (Sugiyono, 2007). Then, randomly picking the schools from each group as the sample was conducted in order to give equal chance for each school to be chosen as the school sample.

There are 10 public senior high schools which were separated by the researcher into three stratified groups which two of them consisted of three schools while the other has four schools based on the average score of admitted freshmen students. The stratification process began by putting all ten schools in ranks from the school with the highest average score of admitted freshmen students to the lowest one before cutting the top four as the top-flight schools' group, the following three schools as the intermediate-flight schools' group, and the last three as the pre-intermediate-flight schools' group. The school grouping is illustrated in detail by table 1. Luckily, the grouping system helped the researcher to decide which schools to involve to represent each schools group. In other words, to find samples of brilliant students, the current researcher needed to randomly pick schools from the top-flight schools' group, while the mediocre students were assumed to be effortlessly found in the less favorite school in each group, and so forth.

Table 1. Average Scores of Admitted Freshmen Students in Each High School in Malang City

\begin{tabular}{ccc}
\hline Group of Schools & Schools & $\begin{array}{c}\text { Freshmen Students' } \\
\text { Average Score }\end{array}$ \\
\hline \multirow{3}{*}{ Top-Flight Schools } & SMA Negeri 3 Kota Malang & 9,54 \\
& SMA Negeri 1 Kota Malang & 9,44 \\
& SMA Negeri 4 Kota Malang & 9,26 \\
& SMA Negeri 5 Kota Malang & 9,16 \\
\hline \multirow{3}{*}{ Intermediate-Flight Schools } & SMA Negeri 8 Kota Malang & 9,05 \\
& SMA Negeri 10 Kota Malang & 8,87 \\
& SMA Negeri 2 Kota Malang & 8,81 \\
\hline \multirow{2}{*}{ Pre-Intermediate-Flight Schools } & SMA Negeri 9 Kota Malang & 8,65 \\
& SMA Negeri 7 Kota Malang & 8,59 \\
& SMA Negeri 6 Kota Malang & 8,23 \\
\hline Source: https://arsip.siap-ppdb.com/2013/malang/\#!/03/arsip retrieved on March 3 ${ }^{\text {rd }}, 2018$.
\end{tabular}

The current researcher conducted random sampling by creating three different pots which represent each group of schools. Then, he was required to fill the pots with the names of schools based on the rank as described in table 2. Hence, in the pot of topflight schools, there were SMAN 3, SMAN 1, SMAN 4, and SMAN 5. The same rule applied to the rest of the pots. Then, the current researcher drew one name of school randomly from each pot to represent each group of schools. The results of the drawing were SMAN 5 from top-flight schools, SMAN 2 from intermediate-flight schools, and SMAN 6 from the pre-intermediate-flight schools.

After the schools to involve had been determined, the following stage to conduct was determining the class to engage in each school. Basically, the researcher only needed three random classes in each school to represent each grade (10th, 11th, and 12th). Unfortunately, the only accessible grade for all three schools were the 11th-grade classes only. Besides, the researcher was also unable to pick the class randomly to collect the data (because random sampling is only applicable on homogenous population), but the teachers in each school do the random picking due to the available schedule instead. However, the minimum number of the class in each school is still fulfilled for the need of the study as the list of samples which table 2 depicts.

After all of the data which were retrieved from three different school during April 2nd to 25th, 2018 and had been tabulated, the current researcher found out that from 301 subjects out of 312 are intact while the rest 11 subjects are damaged due to the failure of the respondents to fill the answer sheet out properly. In detail, there were students who did the reading test well but did not fill out the questionnaire at all. There also were students who did not complete at all or only fill one-third of one of the questionnaire's entire items. Even, there were also students who only did the reading comprehension test but left the section on the provided answer sheets for the questionnaire blank. Consequently, those subjects were unable to put themselves involved in the study because the researcher needs both scores of the questionnaire and the reading test. 
Table 2. Table of Obtained Data during Data Collection Process

\begin{tabular}{ccc}
\hline Names of Schools & $\begin{array}{c}\text { Names of } \\
\text { the Classes }\end{array}$ & $\begin{array}{c}\text { Number of } \\
\text { Students }\end{array}$ \\
\hline SMA Negeri 5 & C4 & 34 \\
Kota Malang & D4 & 30 \\
(Top-Flight Schools) & K4 & 29 \\
\hline \multirow{2}{*}{ SMA Negeri 2 } & XI IPA 1 & 33 \\
Kota Malang & XI IPA 2 & 27 \\
(Intermediate-Flight Schools) & XI IPA 3 & 33 \\
& XI IPA 5 & 31 \\
\hline SMA Negeri 6 & XI BSBU & 18 \\
Kota Malang & XI IPA 1 & 30 \\
(Pre-Intermediate-Flight Schools) & XI IPA 2 & 26 \\
& XI IPS 3 & 21 \\
\hline Total Subjects & & 312 \\
Intact Entries & & 301 \\
Damaged Entries & & 11 \\
\hline
\end{tabular}

This current research involved two kinds of instrument to collect data from two different variables. Those instruments were specific in purpose to find out the reading strategy employed by the students and the reading comprehension score of all students or research subject. So, those instruments were SORS to discover students' reading strategy and reading test to measure student's reading comprehension. Table 3 summarizes the further detail of each instrument's function.

Table 3. Research Instruments

\begin{tabular}{ccl}
\hline Instruments & Variable to Measure & \multicolumn{1}{c}{ Function } \\
\hline SORS & Students' dominant reading strategy & Testing hypothesis of the current study \\
Reading Test & Students' reading comprehension & Testing hypothesis of the current study \\
\hline
\end{tabular}

\section{FINDINGS}

In order to answer research problems by testing the statistical hypotheses, inferential statistics is crucial to conduct. In this current study, there were two processes of inferential statistics analysis namely statistical assumption fulfillment tests and the hypotheses testing. Since the current study employs simple linear regression research design, the statistical assumptions to be fulfilled comprised tests of normality, linearity, heteroscedasticity, and multicollinearity. In short, all four of statistical assumption tests which include normality, linearity, and heteroscedasticity have been conducted yet whose results are not attached. The normality test can be concluded as the data is normally distributed. Afterward, the linearity test also displays results that the criterion variable is linear to the predictor variable. Last, but not least, the heteroscedasticity test also shows that there is no indication of heteroscedasticity in the regression model between the predictor variable and criterion variable.

Since all of the statistical assumption tests are fulfilled, the current researcher is enabled to implement parametric statistical analysis for the further statistical process to test the hypotheses (Creswell, 2010; Kataike, Kulaba, \& Gellynck, n.d.; Sugiyono, 2007). The deployed parametric statistical analysis in the study was simple linear regression analysis whose results is provided in table 4. From table 4, the researcher learned that the Significance column has value came to the level of .051 which is a bit more than the determined significance level of the study (.05). Based on this comparison, the relationship between the predictor variable and the criterion variable can be considered as slightly not significant. Meanwhile, by consulting the table of $t$ values, the value of $t_{\text {table }}$ with 299 as the degree of freedom comes to the level of 1.65 which is less than the obtained the value of $\mathrm{t}_{\text {observe }}$ (1.958). Regarding the fact that $\mathrm{t}_{\text {table }}$ is less than $\mathrm{t}_{\mathrm{observ}}$, the comparison leads to conclusion that the criterion variable is correlated to the predictor variable. Furthermore, table 5 is the Model Summary table retrieved from the regression result. From table 5, the researcher discover the coefficient of determination value from the column of $\mathrm{R}$ Square which leads to the conclusion that only $1.3 \%$ of criterion variable is determined by the predictor variable, while the rest $98.7 \%$ is determined by other factors beyond the criterion variable of the study. This percentage is proven to be very low and almost insignificant. To conclude, two out of three parameters indicate that there is no/very low relationship between the predictor variable and criterion variable. In other word, there is no relationship between both variables of the study. 
Table 4. The Result of Simple Linear Regression Analysis

\begin{tabular}{ccccccc}
\hline \multicolumn{7}{c}{ Coefficients $^{\mathbf{a}}$} \\
\hline \multirow{2}{*}{ Model } & & \multicolumn{7}{c}{ Unstandardized Coefficient } & Standardized Coefficient & S \\
\cline { 3 - 7 } & & $\mathbf{B}$ & Std. Error & Beta & Sig. \\
\hline \multirow{2}{*}{1} & (Constant) & 53.768 & 5.469 & & 9.831 & .000 \\
\cline { 2 - 7 } & Support RS & 3.051 & 1.558 & .113 & 1.958 & .051 \\
\hline
\end{tabular}

a. Dependent Variable: Reading Comprehension

Table 5. Model Summary

\begin{tabular}{|c|c|c|c|c|}
\hline Model & $\mathbf{R}$ & R Square & Adjusted R Square & Std. Error of the Estimate \\
\hline 1 & $.113^{\mathrm{a}}$ & .013 & .009 & 16.22646 \\
\hline
\end{tabular}

\section{DISCUSSION}

From the findings, the current researcher discovered that Support Reading Strategy which was proposed by (Mokhtari \& Sheorey, 2002) does not have any significant relationship with reading comprehension. As previously mentioned, this reading strategy is actually a group of reading strategy which covers several technical reading strategies which are mostly about note taking, making marks on the text, and translating during reading. Unfortunately, in this case, the strategy is not proven to be in good favor toward reading comprehension. This outcome is contradictory to most previous studies which attempted to discover the relationship among reading comprehension and aforementioned technical reading strategies. One of which is the research conducted by (Hagen, Braasch, \& Bråten, 2014) whose finding is slightly controverting one of the findings of the current study. In this support RS is proven to be the failing group of reading strategies to be significantly contributive toward reading comprehension. These groups of reading strategy cover about having a purpose in mind before reading and taking note to help comprehension. In contrary, the research conducted by (Hagen et al., 2014) proves it conversely in which partially their study comes to findings that prior knowledge correlates strongly to reading comprehension across given experimental conditions in a positive manner and different purposes in mind before reading even with note taking during reading leads to varying levels of textual comprehension (Hagen et al., 2014). Despite the different purposes of reading, having a purpose in reading correlates to better comprehension than no purpose before and/or during a reading activity at all.

Numbers of studies have also been conducted whose outcomes are in the spirit of the fact that note-taking during reading affects comprehension level. Taking (Kobayashi, 2009a) for example, he proves that readers who use external strategy (note taking) during reading outperform those who are not in the context of comprehension. He also adds that readers with the purpose to negotiate covert meaning within the text they read before connecting it to another text achieve better comprehension compared to those who read with intention solely to make an opinion about the text (Kobayashi, 2009a: 319). Besides, in his other study, (Kobayashi, 2009b) proves that utilizing highlighting strategy, which covers making marks, underlines, brackets, circles, or even boxes on a portion of the given text (such as a word, a phrase, a sentence, or even a paragraph) in order to highlight particular information does good favor on comprehension level.

Unfortunately, the findings of the current study display the vice versa in which generally students who were involved in the study do not find taking note and/or highlighting important information during reading as the resourceful strategies to boost their reading comprehension. These contrastive previous studies' results actually also confirm another traditional research which was conducted by (Kiewra, Dubois, Christensen, Kim, \& Lindberg, 1989) who proved that readers who are assigned to make structural note about the given text perform better in a synthesis test which measures their ability of pattern identification across several categories of information in the given passage compared to the other groups of reader with different tasks of note-taking assigned to them. They also elaborate further that this condition may be caused by the fact that the other tasks of note-taking are in more advanced instructions where the note to take is more than mentioning important information within the text but also put in a particular order as assigned. Nevertheless, the manifested condition which probably serves as a significant role in putting structural role as the most beneficial note-taking assignment does not undermine the main attitude of the study conducted by (Kiewra et al., 1989) contradictorily toward the partial outcome of the current study.

\section{CONCLUSIONS}

In the current section, the conclusion of the current study is inferred and presented with the strength and weakness of the study following afterward in the same section. Furthermore, the chapter is wrapped up with a subchapter containing the recommendations given by the current researcher in regards to the findings of the current research. 


\section{Conclusions and the Study's Strength and Weakness}

Regarding the findings and the result of their interpretation, the current researcher generally infers that the involved reading strategy in the current research does not have any relationship with reading comprehension. In fact, there is a bit influence by the reading strategy proven by the determined coefficient of determination. Unfortunately, the value of the coefficient is far too low so that it is enough to be considered as insignificant or not correlated.

Beside the positive relationship discovered in the findings of the study, readers of the current study need to be aware and careful that this study bears several limitedness which leads to its weakness or imperfection which may affect the findings. This limitedness is due to the time of data collection, ratio of research subjects from each school, restriction to pick classes of samples in a school, and accessible freshmen student enrollment in high school in Malang. First, time of data collection leads to coverage of allowed students to be picked as samples of this study. In all three picked randomly schools, only the 11th graders who were available since the 12th graders are undisputed to interfere as they are preparing for the national examination, while the 10th graders have not got lessons of types of text utilized in the study. So, all three schools were on the same line where only 11th graders who are available for the study. Secondly, the current researcher was limited to pick subjects from schools in the number the researcher expect. Most of the time, the researcher was asked to conduct the research in more classes than the designed one by the teachers in charge. Teacher of a school was excited with the current study to help him measure the comprehension of his students, while the other teacher wanted the researcher to replace her in her English classes (by conducting the research) as she was busy doing her administrative obligations as an English teacher for one whole week. Consequently, it was only a school which was strictly giving three classes for the study, while the other two gave one class more, even the ratio of involved students from each school are quite identical $(93,124$, and 95$)$. Third, the current researcher was not unimpeded to pick any classes to conduct the study. In fact, the schools who decide which classes were available for the researcher to conduct his study. One school proportionally picked three classes to represent two majors there, while the other two misused the opportunity to replace most and even the entire classroom activities in a meeting. Last, but not least, the current researcher was limited to the accessible data of student enrollment in public senior high schools in the municipal area of Malang. Consequently, the current researcher was not able to classify those public schools based on the recapitulation of the latest freshmen student enrollment.

Despite the weaknesses, the current study spares a strength which is in the form of uniqueness. The current researcher realizes that there have been many research projects conducted to discover or measure the contribution of reading strategy toward reading comprehension. This current study is unique because the involved reading strategy is not what commonly measured which are in an individual manner. This study puts reading strategy in groups which is far less familiar to the research of reading strategy in Indonesia. Based on the findings and the conclusions of the study, the current researcher raises several recommendations in regards to this current study. The recommendations are categorized into two classifications and addressed to two parties: future researchers and English teachers.

For the future researchers, the current researcher recommends to conduct study in line with the study but deeper by taking only one group of the rest reading strategy proposed by (Mokhtari \& Sheorey, 2002) whether it is Global RS or Problem Solving RS because in each group there are separated technical reading strategies which may differ in results if applied to different samples or populations. This kind of research can also be conducted with junior high school students because the formal education in Indonesia introduces English mandatorily in junior high school level instead of at the earlier level such as primary school. Conducting it to junior high schools students are aimed to discover which one of these groups of reading strategy is the most contributive toward the early learner of English. Furthermore, the findings may help junior high school teachers to introduce reading strategies to their students in order to boost their student's reading comprehension.

For English teachers, involving reading strategies in the process to pursue reading comprehension has been proven to be effective and helpful. Thus, the current researcher recommends introducing a reading strategy including practicing the way to use it during the process of teaching reading. By making students used to utilize the proper reading strategy, students' reading comprehension is expected to be increased because the proses of grasping ideas of the text go more effectively. Since the global reading strategy is the most common reading strategy to use, teachers may begin the introduction of the reading strategy with strategies under the global reading strategy. Once the students have mastered the strategies well, the teachers may proceed to the other groups of reading strategy. Teachers can train their students with the groups in turns like illustrated in the last few sentences or concurrently by paying attention to students' rate of mastery to make sure students recognize the strategies well including when to utilize them. 


\section{REFERENCES}

Abrami, P. C., Bernard, R. M., Borokhovski, E., Surkes, M. A., Tamim, R., \& Zhang, D. (2008). Instructional Interventions Affecting Critical Thinking Skills and Dispositions : A Stage 1 Meta-Analysis. 78(4), 1102-1134. https://doi.org/10.3102/0034654308326084

Alfassi, M. (2004). Reading to Learn: Effects of Combined Strategy Instruction on High School Students. The Journal of Educational Research, 97(4), 171-185.

Brown, H., \& Lee, H. (2015). Teaching by Principles: An Interactive Approach to Language Pedagogy (Fourth Ed). London: White Palms: Pearson Education Inc.

Creswell, J. (2010). Research Design Qualitative and Mixed Qualitative Approach. Yogyakarta: Pustaka Pelajar.

Gebhard, J. G. (1996). Teaching English as a Foreign or Second Language: A Self-Development Guide. Ann Arbor: University Michigan Press.

Gilakjani, A. P., \& Sabouri, N. B. (2016). A Study of Factors Affecting EFL Learners' Reading Comprehension Skill and the Strategies for Improvement. International Journal of English Linguistics, 6(5), 180-187.

Gilliam, S., Magliano, J. P., Millis, K. K., Levinstein, I., \& Boonthum, C. (2007). Assessing the format of the presentation of text in developing a Reading Strategy Assessment Tool (R-SAT). Behavior Research Methods, 39(2), $199-204$.

Grabe, W. (1991). Current Developments in Second Language Reading Research. TESOL Quarterly, 25(3), 375-406.

Hagen, Å. M., Braasch, J. L. G., \& Bråten, I. (2014). Relationships Between Spontaneous Note-Taking, Self-Reported Strategies and Comprehension when Reading Multiple Texts in Different Task Conditions. Journal of Research in Reading, 37(S1), S141-S157.

Jafari, S. M., \& Shokrpour, N. (2012). The Reading Strategies Used by Iranian ESP Students to Comprehend Authentic Expository Texts in English. International Journal of Applied Linguistics and English Literature, 1(4), 102-113.

Kataike, J., Kulaba, J., \& Gellynck, X. (n.d.). What Junior Researchers Must Know Before and After Data Collection: Difference between Parametric and Nonparametric Statistics.

Kiewra, K. A., Dubois, N. F., Christensen, M., Kim, S. I., \& Lindberg, N. (1989). A More Equitable Account of the NoteTaking Functions in Learning from Lecture and from Text. Instructional Science, 18(3), 217-232.

Kobayashi, K. (2009a). Comprehension of Relations Among Controversial Texts: Effects of External Strategy Use. Instructional Science, 37(4), 311-324.

Kobayashi, K. (2009b). The Influence of Topic Knowledge, External Strategy Use, and College Experience on Students' Comprehension of Controversial Texts. Learning and Individual Differences, 19(1), 130-134.

Koda, K. (2007). Reading and language learning: Crosslinguistic Constraints on Second Language Reading Development. Language Learning, 57, 1-44. https://doi.org/https://doi.org/10.1111/0023-8333.101997010-i1

Manoli, P. G. (2013). Developing Reading Strategies in Elementary EFL Classrooms. University of Thessaly.

Margono, S. (2004). Metode Penelitian Pendidikan. Jakarta: Rineka Cipta.

Mokhtari, K., \& Sheorey, R. (2002). Measuring ESL Students' Awareness of Reading Strategies. Journal of Developmental Education, 25(3), 2-11.

Musya'idah, M., \& Effendy, E. Santoso, A. (2016). POGIL, Analogi Model FAR, KBI, dan Laju Reaksi. Prosiding Semnas Pendidikan IPA Pascasarjana Universitas Negeri Malang, 671-680.

Nergis, A. (2013). Exploring the Factors that Affect Reading Comprehension of EAP Learners. Journal of English for Academic Purposes, 12(1), 1-9.

Nosratinia, M., \& Shakeri, H. (2013). Does Reading Strategy Use Correlate with Reading Comprehension of Efl Learners? International Journal of Arts \& Sciences, 6(3), 299.

Permatasari, A. (2015). Reading Anxiety, Self-Efficacy, Reading Strategy Use, and Reading Comprehension of Indonesian EFL College Students. Unpublished Thesis. Universitas Negeri Malang, Malang.

Pressley, M., \& Afflerbach, P. (2012). Verbal Protocols of Reading: The Nature of Constructively Responsive Reading. Routledge.

Sanford, K. L. (2015). Factors that Affect the Reading Comprehension of Secondary Students with Disabilities.

Sugiyono, S. (2007). Statistika untuk Penelitian. Bandung: Alfabeta.

Sulistyo, G. H. (2011). Reading for Meaning. Malang: Pustaka Kaiswaran.

Tiruneh, D. T., De Cock, M., \& Elen, J. (2018). Designing Learning Environments for Critical Thinking: Examining Effective instructional Approaches. International Journal of Science and Mathematics Education, 16(6), 1065-1089. https://doi.org/https://doi.org/10.1007/s10763-017-9829-z

Urquhart, A. H., \& Weir, C. J. (2014). Reading in a Second Language: Process, Product and Practice. Routledge.

Whitley, B. E., \& Kite, M. E. (2013). Principles of Research in Behavioral Science. Routledge. 
Widyawati, S. (2017). Siswa SMA dan SMK se-Malang Raya Bisa Bangga, Perhatikan Hasil UNBK Ini. Retrieved from SuryaMalang.com website: http://suryamalang.tribunnews.com/2017/04/29/siswa-sma-dan-smk-se-malang-raya-bisabangga-perhatikan-hasil-unbk-ini

Williams, E., \& Moran, C. (1989). Reading in a Foreign Language at Intermediate and Advanced Levels with Particular Reference to English. Language Teaching, 22(4), 217-228.

Zare, M., \& Mobarakeh, S. D. (2011). The Relationship Between Self-Efficacy and Use of Reading Strategies: The Case of Iranian Senior High School Students. Studies in Literature and Language, 3(3), 98.

Zoghi, M., Mustapha, R., \& Maasum, T. N. R. T. M. (2010). Looking into EFL Reading Comprehension. Procedia-Social and Behavioral Sciences, 7, 439-445. 